\title{
The cellular composition of induced sputum in chronic obstructive pulmonary disease
}

\author{
R.A. Peleman, P.H. Rytilä, J.C. Kips, G.F. Joos, R.A. Pauwels
}

The cellular composition of induced sputum in chronic obstructive pulmonary disease. R.A. Peleman, P.H. Rytilä, J.C. Kips, G.F. Joos, R.A. Pauwels. (C)ERS Journals Ltd 1999.

ABSTRACT: Asthma and chronic obstructive pulmonary disease are characterized by airway inflammation, which can be assessed by bronchoscopic techniques as well as by the analysis of induced sputum.

A method to induce sputum with inhaled hypertonic saline was adapted for use in 21 chronic obstructive pulmonary disease (COPD) patients (mean baseline forced expiratory volume in one second (FEV1) $1.60 \mathrm{~L}$, or $54 \%$ predicted) and in 16 healthy volunteers. The success rate and safety of the method, were investigated along with the reproducibility of cell counts and differences in cell counts between both groups.

All subjects produced adequate samples and the procedure did not alter spirometric values. A marked sputum neutrophilia was noted in patients with COPD $(74.9 \pm 4.7 \%)$, whereas mainly macrophages were seen in healthy volunteers $(\mathbf{7 4 . 0} \pm 4.0 \%)$. Reliability of the cell counts was high, both within investigators $(r=0.99$ neutrophils, $r=0.99$ macrophages) and between investigators ( $r=0.95$ neutrophils, $r=0.77$ macrophages). In patients with COPD, an inverse correlation was noted between percentage of neutrophils and FEV1 $\left(r_{s}=\mathbf{- 0 . 4 8 , p}<0.05\right)$. Immunostaining revealed a large proportion of activated macrophages in both groups.

It was concluded that induction of sputum is a safe and reproducible method to study the composition of airway secretions in patients with chronic obstructive pulmonary disease.

Eur Respir J 1999; 13: 839-843.

Inflammation plays a key role in the pathophysiology of asthma [1] but whether it is also central to the pathophysiology of other forms of chronic obstructive airway disorders, such as chronic obstructive pulmonary disease (COPD) and chronic bronchitis remains to be fully investigated. In biopsies of patients with asthma primarily eosinophils, monocytes and T-lymphocytes $[2,3]$ are seen, but a predominant infiltration of mononuclear inflammatory cells with few polymorphonuclear cells was seen in surgically resected specimens of patients with chronic bronchitis [4]. Moreover, in lobar bronchial biopsies of subjects with chronic bronchitis, an increased number of leukocytes, both in the epithelium and in the lamina propria, consisting predominantly of macrophages and activated T-cells was found [5]. In order to overcome the difficulties associated with bronchoalveolar lavage and the sampling of bronchial biopsies via the bronchoscope, analysis of spontaneously produced or induced sputum has recently been suggested for repeated evaluation of airway inflammation in patients with asthma [6-8], chronic bronchitis [7-9] and COPD [9]. The aim of the present study was to assess the success rate, reproducibility and safety of a method for sputum induction in patients with severe COPD and to compare the differential cell counts and immunocytochemical analysis with sputum obtained from healthy volunteers (HV).
Dept of Respiratory Diseases, University Hospital, Ghent, Belgium.

Correspondence: R.A. Peleman

Dept of Respiratory Diseases

University Hospital Ghent

De Pintelaan 185 B-9000

Ghent

Belgium

Fax: 3292402341

Keywords: Chronic obstructive pulmonary disease neutrophils

sputum

Received: February 51998

Accepted after revision November 71998

Supported by grants $3.0107 .93,3.0033 .94$ and 3.0077.96 from the Nationaal Fonds voor Wetenschappelijk Onderzoek, Belgium.

Material and methods

\section{Subjects}

In a prospective study 21 patients with a poorly reversible airflow obstruction were analysed (table 1). Their diagnosis was based on consensus criteria [10]. None of the patients had a respiratory tract infection within the 4 weeks preceding the procedure. The patients pre-bronchodilator forced expiratory volume in one second (FEV1) was $1.6 \pm 0.1 \mathrm{~L}($ mean $\pm \mathrm{SEM})$ or $54 \%$ predicted, with an increase in FEV $1<10 \%$ pred after $400 \mu \mathrm{g}$ salbutamol. All patients were exsmokers (stopped at least $1 \mathrm{yr}$ before study entry). They had smoked for a mean $37.0 \pm 2.7$ packyrs. The healthy controls (sex, but not age-matched) were selected from the hospital employees and were nonatopic nonsmokers with a normal pulmonary function. All subjects of both groups had negative skin tests for a panel of allergens. They gave informed consent and the study was approved by the ethics committee of the University Hospital.

\section{Study design}

Subjects visited the laboratory three times. On the first visit subject characteristics were documented and lung 
Table 1. - Individual data of the chronic obstructive pulmonary disease subjects

\begin{tabular}{|c|c|c|c|c|c|c|c|c|}
\hline $\begin{array}{l}\text { Subject } \\
\text { No. }\end{array}$ & Sex & $\begin{array}{l}\text { Age } \\
\text { yrs }\end{array}$ & $\begin{array}{c}\text { FEV1 } \\
\text { L }\end{array}$ & $\begin{array}{l}\text { FEV1 } \\
\% \text { pred }\end{array}$ & $\begin{array}{c}\mathrm{FEV}_{1} / \mathrm{VC} \\
\%\end{array}$ & $\begin{array}{l}\text { Smoking } \\
\text { pack-yrs }\end{array}$ & $\begin{array}{c}D \mathrm{~L}, \mathrm{CO} / V \mathrm{~A} \\
\% \text { pred }\end{array}$ & Medication \\
\hline 1 & M & 76 & 1.13 & 53 & 53 & 60 & 52 & IS, B \\
\hline 2 & M & 53 & 1.36 & 51 & 51 & 25 & 67 & IS, B \\
\hline 3 & M & 68 & 2.07 & 72 & 67 & 40 & 97 & IS, B \\
\hline 4 & M & 68 & 1.24 & 43 & 31 & 47 & 50 & IS \\
\hline 5 & M & 45 & 1.77 & 55 & 45 & 20 & 64 & IS, B \\
\hline 6 & M & 57 & 2.81 & 80 & 59 & 40 & 62 & IS, B \\
\hline 7 & M & 64 & 2.04 & 65 & 58 & 30 & 56 & IS \\
\hline 8 & M & 67 & 2.03 & 71 & 53 & 40 & 68 & IS, B \\
\hline 9 & $\mathrm{~F}$ & 60 & 1.84 & 68 & 62 & 40 & 58 & IS \\
\hline 10 & M & 56 & 1.44 & 36 & 54 & 60 & 91 & IS \\
\hline 11 & M & 52 & 1.31 & 39 & 56 & 55 & 79 & \\
\hline 12 & M & 60 & 1.28 & 43 & 50 & 40 & 42 & IS \\
\hline 13 & M & 58 & 0.71 & 23 & 22 & 35 & 33 & IS, B \\
\hline 14 & M & 52 & 1.50 & 43 & 43 & 35 & 50 & IS, B \\
\hline 15 & $\mathrm{~F}$ & 56 & 1.65 & 59 & 53 & 20 & 56 & IS \\
\hline 16 & $\mathrm{M}$ & 67 & 1.73 & 62 & 67 & 20 & 75 & IS \\
\hline 17 & M & 69 & 1.53 & 50 & 40 & 35 & 51 & IS \\
\hline 18 & M & 63 & 2.13 & 64 & 54 & 30 & 55 & IS \\
\hline 19 & M & 63 & 1.66 & 49 & 62 & 20 & 71 & IS \\
\hline 20 & M & 63 & 1.64 & 55 & 56 & 30 & 73 & IS, B \\
\hline 21 & M & 69 & 1.62 & 53 & 64 & 50 & 52 & IS, B \\
\hline Mean & & 61 & 1.6 & 54 & 53 & 37 & 62 & \\
\hline SEM & & 1.6 & 0.1 & 3 & 2.5 & 2.7 & 3.4 & \\
\hline
\end{tabular}

FEV1: forced expiratory volume in one second; $\mathrm{VC}$ : vital capacity; $D \mathrm{~L}, \mathrm{CO} / \mathrm{VA}$ : diffusion capacity for carbon monoxide per litre/lung (alveolar) volume; IS: inhaled steroids $\left(\leq 1,000 \mu \mathrm{g} \cdot \mathrm{day}^{-1}\right)$; B: inhaled $\beta_{2}$-adrenoceptor agonists p.r.n.; M: male; F: female.

function measurements were performed according to a standardized protocol. Subsequently, subjects underwent sputum induction, at the same time of the day, on 2 days (with an interval of 10 days). Spirometric values were recorded before and after induction by means of a water-

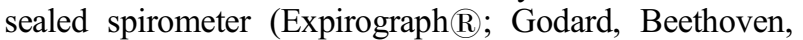
The Netherlands).

\section{Sputum induction}

After the inhalation of salbutamol $(2 \times 200 \mu \mathrm{g})$, subjects were asked to inhale sterile, pyrogen-free, hypertonic saline in increasing concentrations $(3.0,4.0$ and $5.0 \%$, respectively), for a duration of $10 \mathrm{~min}$ each. The hypertonic saline was nebulized via an ultrasonic nebulizer (Ultra-neb; Devilbiss Health Care Inc, Somerset, PA, USA). Subjects were encouraged to cough throughout the procedure. Most patients were able to expectorate an adequate sample (at least $5 \mathrm{~mL}$ ) within the first $10 \mathrm{~min}$.

\section{Sputum processing}

Sputum analysis was performed as previously described [6] and validated [11]. In order to reduce salivary contamination, plugs were selected and transferred into an Eppendorf tube. Freshly prepared 10\% solution of dithiothreitol (1mL) (DTT; Sputalysin, Boehringer-Calbiochem Corp, San Diego, CA, USA) was added. The tube was vortex mixed and the sputum was incubated for $5 \mathrm{~min}$ at room temperature, filtered through $52 \mu \mathrm{m}$ nylon gauze (BNSH Thompson, Scarborough, Ontario, Canada) to remove debris and mucus, and subsequently centrifuged at $450 \times g$ ) for $10 \mathrm{~min}$. The cell pellet was resuspended in phosphate-buffered saline (PBS) in a volume equal to the sputum plus DTT solution volume.

Total cell counting was carried out in a haemocytometer and the cell concentration was adjusted to $1.0 \times 10^{6}$ cells. $\mathrm{mL}^{-1}$. Cytospins were prepared by adding $75 \mu \mathrm{L}$ cell suspension into Shandon II cytocentrifuge cups (Shandon Southern Instruments, Sewickley, PA, USA) and spun for 6 min at $450 \mathrm{rpm}$. Two slides were stained with WrightGiemsa for an overall differential cell count of leukocytes, bronchial epithelial cells and squamous cells. Slides were coded and counted blind by two investigators. None of the cytospins contained $>20 \%$ squamous epithelial cells. For cell differentiation, 400 nucleated cells per slide were counted and expressed as percentage of intact round nucleated cells, excluding the squamous epithelial cells.

\section{Immunocytochemical analysis}

Cytospins obtained from eight healthy persons and from eight subjects with COPD were selected at random, based solely on a homogeneous dispersion on the Wright-Giemsa stained slides, for immunostaining. Cell surface markers were identified by immunocytochemical staining with antibodies against CD3 (pan T-cell), CD4 (helper T-cell), CD8 (suppressor T-cell), CD20 (pan B-cell), CD25 (activated T-cell), CD45 (pan leukocytes), CD68 (macrophages) and Ber-Mac3 (activated macrophages) (Dakopatts, Copenhagen, Denmark) using the alkaline phosphatase anti-alkaline phosphatase (APAAP) method. Cytospins made from peripheral blood leukocytes separated by a Ficoll-Paque (Pharmacia, Uppsala, Sweden) gradient were processed in the same way as the sputum cells and used as a positive control. 


\section{Statistical analysis}

Total and differential counts are presented as mean value (SEM). Differences between groups are analysed using the Mann-Whitney U-test. Probability values of $p<0.05$ were considered significant. Reproducibility of sputum cell counts was examined by a repeated-measures analysis of variance with calculation of the intraclass correlation coefficient, $r$ (the ratio of three variance of cell counts between subjects to the total variance in cell counts including observed and error variance) [12]. Values $>0.75$ indicate high reliability. The intrapatient variability at different time points was also assessed using the coefficient of repeatability (CR), representing the limits of agreement within which $95 \%$ of the differences are expected to be found [13]. Spearman's rank correlation $\left(r_{s}\right)$ was calculated to assess the relationship between patient characteristics, lung function parameters and the cell differential count in the induced sputum COPD patients

\section{Results}

\section{Safety and success of the method}

The procedure was well tolerated by all subjects. Patients with COPD did not report adverse events nor worsening dyspnoea upon induction. In 16 out of 21 patients, spirometry was performed before and after the inhalation of hypertonic saline. No significant change in FEV1 was seen (FEV1 pre-inhalation: $1.22 \pm 0.17 \mathrm{~L}, \mathrm{FEV} 1$ post-inhalation: $1.18 \pm 0.2 \mathrm{~L}$ ).

\section{Reproducibility of sputum cell counts}

To examine the reproducibility of sputum cell differential counts in COPD patients the intraclass correlation coefficient $r$ was calculated. For neutrophils and macrophages, the reproducibility was high, both within investigators ( $r=0.99$ neutrophils, $r=0.99$ macrophages, $r=0.33$ lymphocytes, $\mathrm{r}=0.30$ eosinophils) and between investigators $(r=0.95$ neutrophils, $r=0.77$ macrophages, $r=0.16$ lymphocytes, $\mathrm{r}=0.16$ eosinophils). To examine the withinsubject variability, cell differential counts in two sputum samples induced at a 10-day interval were compared. The coefficients of repeatability are shown in table 2 .

Table 2. - Reproducibility of cell differential count

\begin{tabular}{lrrrr}
\hline Parameter & \multicolumn{1}{c}{ Week 1 } & Week 2 & \multicolumn{1}{c}{$\mathrm{C}_{\mathrm{r}}$} & $\mathrm{r}$ \\
\hline Total $\left(\times 10^{3} \cdot \mathrm{mg}^{-1}\right)$ & $23.6(5.8)$ & $38.4(11.4)$ & & \\
Neutrophils \% & $74.9(4.7)$ & $75.9(4.1)$ & 19.2 & 0.84 \\
Marcrophages \% & $20.9(3.5)$ & $19.1(2.8)$ & 17.5 & 0.67 \\
Eosinophils \% & $2.4(1.7)$ & $3.1(1.6)$ & 3.2 & 0.90 \\
Lymphocytes \% & $0.6(0.2)$ & $0.6(0.2)$ & 1.7 & 0.30 \\
Bronchial cells \% & $1.1(0.7)$ & $1.1(0.6)$ & 2.3 & 0.91 \\
\hline
\end{tabular}

Values are means (SEM), $n=21$. $C_{r}$ : coefficient of repeatability; $r$ : intraclass correlation coefficient.

\section{Differential cell counts}

Patients with COPD had a higher total cell number $\left(23.60 \pm 5.8 \times 10^{3}\right.$ cells $\cdot \mathrm{mg}^{-1}$ versus $\mathrm{HV} 5.1 \pm 0.8 \times 10^{3}$ cells. $\left.\mathrm{mg}^{-1}, \mathrm{p}<0.002\right)$, an increased percentage of neutrophils $(74.9 \pm 4.5$ versus $\mathrm{HV} 22.5 \pm 4.7, \mathrm{p}<0.001)$ and a decreased percentage of macrophages $(20.9 \pm 3.5$ versus $\mathrm{HV} 74.0 \pm 4.0$ $\mathrm{p}<0.001)$. No difference was noted between COPD and $\mathrm{HV}$ in the percentage of lymphocytes, eosinophils, and bronchial epithelial cells. In patients with COPD, only the percentage of neutrophils correlated inversely with their FEV1 $\left(\mathrm{r}_{\mathrm{s}}=-0.48, \mathrm{p}<0.05\right)$ (fig. 1).

\section{Immunocytochemical analysis}

To further characterize the inflammatory component in COPD patients, cytospin preparations of both $\mathrm{HV}(\mathrm{n}=8)$ and COPD patients $(n=8)$ were used for immunocytochemistry. Analysis of cell surface markers by the APAAP technique demonstrated very few $\mathrm{CD} 3+, \mathrm{CD} 4+$ and $\mathrm{CD} 8+$ and no CD20+ or CD25+ cells. The percentage of CD45+ cells $(80.5 \pm 5.5$ versus $52.6 \pm 6.1, \mathrm{p}=0.007)$ was significantly higher in COPD patients. In both groups, the majority of the macrophages (stained for CD68) were activated, as indicated by the positive staining with BerMac3 (table 3).

\section{Discussion}

In this study the safety and reproducibility of sputum induction in COPD patients was examined. The cellular composition of induced sputum of COPD patients was compared with sputum from healthy volunteers. In order to avoid inadvertent bronchoconstriction reported to occur in asthmatics [14], all subjects received pretreatment with salbutamol. None of the subjects reported worsening dyspnoea nor did the spirometry values differ significantly before and after inhalation of hypertonic saline, indicating that the procedure is safe. It was also demonstrated that this method of sputum processing is reproducible as assessed

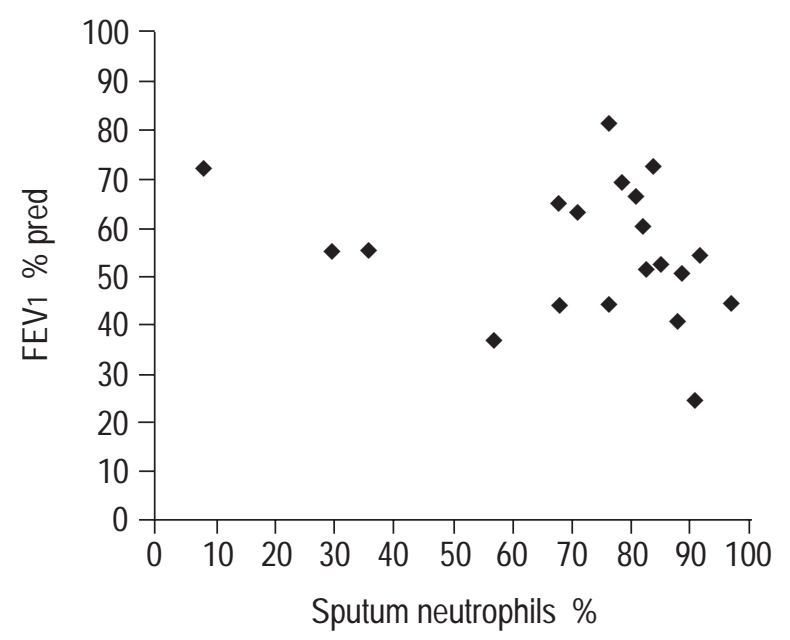

Fig. 1. - Plot of the differential counts of neutrophils (as percentages) against forced expiratory volume in one second (FEV1) \% predicted measured before sputum collection in patients with chronic obstructive pulmonary disease. 
Table 3. - Cell surface markers in induced sputum as analysed with the alkaline phosphatase anti-alkaline phosphatase (APAAP) technique

\begin{tabular}{lcc}
\hline Parameter & COPD & Healthy \\
\hline CD 3\% & $1.8(0.7)$ & $2.1(0.5)$ \\
CD $4 \%$ & $0.1(0.1)$ & $2.1(0.2)$ \\
CD $8 \%$ & $0.3(0.1)$ & $0.4(0.2)$ \\
CD 68 \% & $17.9(4.8)$ & $71.2(4.5)^{*}$ \\
Ber-Mac 3 \% & $10.1(2.2)$ & $47.4(74)^{*}$ \\
Ber-Mac3/CD68 & 56 & 66 \\
\hline
\end{tabular}

Values are expressed as means (SEM), $n=8$ in both groups, calculated as percentage of nonsquamous cells. The proportion of activated macrophages is expressed as percentage of number of macrophages. COPD: chronic obstructive pulmonary disease. *: $\mathrm{p}<0.05$, Mann-Whitney U-test.

by an intraclass coefficient for neutrophils and macrophages $>0.75$. To assess the within-subject reproducibility of induced sputum differential cell counts, sputum was induced on different occasions and a high coefficient of repeatability was found for macrophages and neutrophils only. High coefficients of reproducibility of cell counts in normal subjects have been demonstrated previously $[6,11]$ with intraclass correlation coefficients of $>0.7$ for all cell types except lymphocytes (0.3) and total cell counts (0.4). Analogous results were also demonstrated in asthmatics [15]. The methods of sputum "plug" selection used in those studies as well as in the present study may account for the improved reproducibility of total cell counts by reducing the salivary contamination. Whereas the reproducibility for counts of macrophages and neutrophils is high, poorer results are seen for lymphocytes and eosinophils. This is possibly due to the presence of much lower numbers of these cells than the abundance of macrophages and neutrophils.

In this study the cellular composition of induced sputum of COPD patients was compared with healthy volunteers. Induced sputum in COPD contains mainly neutrophils at a percentage that is almost reciprocal to that of macrophages in healthy volunteers. These observations are in line with previous findings of high percentages of intraluminal neutrophils $[8,16]$ and confirm previous studies demonstrating an increased number of neutrophils in bronchoalveolar lavage fluid $[16,17]$. The finding that the highest neutrophil percentages were found in patients with the worst airflow obstruction is in agreement with the hypothesis that neutrophilic inflammation of the small bronchi is an important factor in the pathogenesis of airflow limitation in COPD. It has been shown that small bronchi and bronchioli are the major site of increased airflow resistance in COPD [18] and that inflammatory changes at these sites correlate with airflow limitation [19]. Assuming that induced sputum contains material from the lower airways, this technique may be a useful tool to study airway inflammation in COPD. Some discrepancies may still exist, as were shown in one study in chronic bronchitics with relatively mild airway obstruction, where the increase in the number of neutrophils and lymphocytes in the bronchial biopsies of subjects with exacerbations was not detected in sputum [9]. The disparity between low numbers of neutrophils in biopsies and high numbers in bronchoalveolar lavage and in sputum could be due to either rapid migration through the epithelium or to a preferential peripheral location.

The excellent dispersion seen on cytospin slides allows for the application of immunocytochemical techniques. Very few CD4+ and CD8+ and no CD20+ or CD25+ cells were detected. In both groups most of the macrophages were activated as shown by the high percentage of macrophages expressing the antigen M130, recognized by the antibody Ber-Mac 3 [20]. A significantly higher number of activated macrophages was also found in bronchoalveolar lavage of asthmatics than in normal subjects [21]. However, in view of the methodological differences, the present data cannot directly be compared with this study.

In summary, the analysis of induced sputum was concluded to be a safe and reproducible method to study inflammatory cells in patients with chronic obstructive pulmonary disease. High numbers of neutrophils were found in chronic obstructive pulmonary disease and an almost reciprocal number of macrophages in healthy volunteers. A significant negative correlation was also found between sputum neutrophilia and forced expiratory volume in one second.

\footnotetext{
Acknowledgements. R.A. Peleman and P.H. Rytila contributed equally to this study.
}

\section{References}

1. Djukanovic R, Roche WR, Wilson JW, et al. Mucosal inflammation in asthma. Am Rev Respir Dis 1990; 142: 434-457.

2. Saetta M, Di Stefano A, Rosina C, Thiene G, Fabbri L. Quantitative structural analysis of peripheral airways and arteries in sudden fatal asthma. Am Rev Respir Dis 1991; 143: $138-143$.

3. Azzawi M, Johnston PW, Majumdar S, Kay AB, Jeffery PK. T lymphocytes and activated eosinophils in asthma and cystic fibrosis. Am Rev Respir Dis 1991; 145: 14771482.

4. Mullen JBM, Wright JL, Wiggs BR, Pare PD, Hogg JC. Reassessment of inflammation of airways in chronic bronchitis. Br Med J 1985; 291: 1235-1239.

5. Saetta M, Di Stefano A, Maestrelli P, et al. Activated Tlymphocytes and macrophages in bronchial mucosa of subjects with chronic bronchitis. Am Rev Respir Dis 1993; 147: 301-306.

6. Pin I, Gibson PG, Kolendowicz R, et al. Use of induced sputum cell counts to investigate airway inflammation in asthma. Thorax 1992; 47: 25-29.

7. Gibson PG, Girgis-Gabardo A, Morris MM, et al. Cellular characteristics of sputum from patients with asthma and chronic bronchitis. Thorax 1989; 44: 693-699.

8. Keatings VM, Collins PD, Scott DM, Barnes PJ. Differences in interleukin- 8 and tumor necrosis factor- $\alpha$ in induced sputum from patients with chronic obstructive pulmonale disease or asthma. Am J Respir Crit Care Med 1996; 153: 530-534.

9. Saetta M, Di Stefano AD, Maestrelli P, et al. Airway eosinophilia in chronic bronchitis during exacerbations. Am J Respir Crit Care Med 1994; 150: 1646-1652.

10. Siafakas NM, Vermeire P, Pride NB, et al. On behalf of the Task Force. Optimal assessment and management of chronic obstructive pulmonary disease (COPD). Eur Respir $J$ 1995; 8: 1398-1420. 
11. Pizzichini E, Pizzichi MMM, Efthimiadis A, et al. Indices of airway inflammation in induced sputum: reproducibility and validity of cell and fluid-phase measurements. Am J Respir Crit Care Med 1996; 154: 308-317.

12. Kramer MS, Feinstein AR. Clinical biostatistics: LIV. The biostatistics of concordance. Clin Pharmacol Ther 1981; 29: 111-123.

13. Bland JM, Altman DG. Statistical methods for assessing agreement between two methods of clinical measurement. Lancet 1986; i: 307-310.

14. Wong HH, Fahy JV. Safety of one method of sputum induction in asthmatic subjects. Am J Respir Crit Care Med 1997; 156: 299-303.

15. In 't Veen JCCM, de Gouw HWFM, Smits HH, et al. Repeatability of cellular and soluble markers of inflammation in induced sputum from patients with asthma. Eur Respir J 1996; 9: 2441-2447.

16. Thompson AB, Daughton D, Robbins RA, Ghafouri MA, Oehlerking M, Rennard SI. Intraluminal airway inflammation in chronic bronchitis. Am Rev Respir Dis 1989; 140: $1527-1537$.
17. Linden M, Rasmussen JBO, Piitulainen E, et al. Airway inflammation in smokers with nonobstructive and obstructive chronic bronchitis. Am Rev Respir Dis 1993; 148: $1226-1232$.

18. Hogg JC, Maclem PT, Thurlbeck WM. Site and nature of airway obstruction in chronic obstructive lung disease. $N$ Engl J Med 1968; 278: 1355-1360.

19. Cosio MG, Hale KA, Niewoehner DE. Morphologic and morphometric effects of prolonged cigarette smoking on the small airways. Am Rev Respir Dis 1980; 122: 265271.

20. Law A, Macklem KJ, Shaw JM, et al. A new macrophage differentiation antigen which is a member of the scavenger receptor superfamily. Eur J Immunol 1993; 23: 2320-2325.

21. Viksman MY, Liu MC, Bickel CA, Schleimer RP, Bochner BS. Phenotypic analysis of alveolar macrophages and monocytes in allergic airway inflammation. I. Evidence for activation of alveolar macrophages, but not peripheral blood monocytes, in subjects with allergic rhinitis and asthma. Am J Respir Crit Care Med 1997; 155: 858-863. 